\title{
Cell wall perturbation in yeast results in dual phosphorylation of the SIt2/Mpk1 MAP kinase and in an Slt2-mediated increase in FKS2-lacZ expression, glucanase resistance and thermotolerance
}

\author{
Hans de Nobel, ${ }^{1}$ Cristina Ruiz, ${ }^{2}$ Humberto Martin, ${ }^{2}$ Wayne Morris, ${ }^{1,3}+$ \\ Stanley Brul, ${ }^{1,3}$ Maria Molina ${ }^{2}$ and Frans M. Klis ${ }^{1}$
}

\begin{abstract}
Author for correspondence: Hans de Nobel. Tel: +31 20 5257850. Fax: +31 205257934 e-mail: nobel@bio.uva.n
\end{abstract}

1 Center for Fungal Cell Wall Research, Swammerdam Institute for Life Sciences, BioCentrum, University of Amsterdam, Kruislaan 318, 1098 SM Amsterdam, The Netherlands

2 Departamento de Microbiología II, Facultad Farmacia, UCM, Avda. Ramón y Cajal s/n 28040Madrid, Spain

3 Department of Microbiology and Preservation, Unilever Research Laboratory, Olivier van Noortlaan 120, 3133 AT Vlaardingen, The Netherlands

\begin{abstract}
The protein kinase C (PKC1) pathway is essential for maintaining cell integrity in yeast. Here it is shown that various forms of cell wall damage result in activation of the downstream MAP kinase SIt2/Mpk1. Several cell wall mutants displayed enhanced FKS2-lacZ expression, a known output of Slt2 activation. A similar response was obtained with wild-type cells grown in the presence of the cell wall perturbants Calcofluor white and Zymolyase. Upregulation of FKS2-lacZ in response to sublethal concentrations of these agents fully depended on the presence of SIt2. The same cell wall stress conditions resulted in dual threonine and tyrosine phosphorylation of SIt2. Both SIt2 phosphorylation and FKS2-lacZ induction could be largely prevented by providing osmotic support to the plasma membrane. Interestingly, SIt2 phosphorylation in response to cell wall damage required the putative plasmamembrane-located sensor Mid2 but not Hcs77/Wsc1. Finally, cell wall perturbation gave rise to cells with increased resistance to glucanase digestion and heat shock. These responses depended on the presence of SIt2. These results indicate that weakening of the cell wall activates the SIt2/Mpk1 MAP kinase pathway and results in compensatory changes in the cell wall.
\end{abstract}

Keywords: wall damage, wall integrity, Slt2, Mid2, thermotolerance

\section{INTRODUCTION}

The yeast cell wall is an essential organelle that, due to its mechanical strength, is able to resist internal turgor pressure and consequently prevents cell lysis. Synthesis and assembly of 1,3- $\beta$-glucan are required for the construction of a strong and functional wall. FKS1 encodes a subunit of the yeast 1,3- $\beta$-glucan synthase (Mazur et al., 1995) and Gas1 is involved in remodelling of 1,3- $\beta$-glucan (Popolo \& Vai, 1999). Loss of either of these two plasma-membrane-localized proteins results in significantly reduced levels of 1,3 - $\beta$-glucan in the wall and in the formation of viable but swollen cells (Ram et

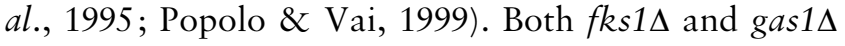

\footnotetext{
+Present address: Fungal \& Bacterial Plant Pathology Department, Scottish Crop Research Institute, Invergowrie, Dundee DD2 5DA, UK.

Abbreviation: CFW, Calcofluor white.
}

cells also display an increase in chitin content and in the expression of the alternative subunit of the yeast $1,3-\beta$ glucan synthase, Fks2 (Mazur et al., 1995; Ram et al., 1998). These changes have been proposed to be part of a set of compensatory reactions to ensure cell wall integrity. Simultaneous depletion of protein kinase $\mathrm{C}$ in these mutants is lethal, suggesting that their viability depends on signalling through the PKC1-controlled cell integrity pathway (Garrett-Engele et al., 1995 ; Popolo et al., 1997).

Protein kinase $\mathrm{C}$ activates a linear MAP kinase cascade that consists of a MAPKK kinase, Bck1/Slk1; a pair of redundant MAPK kinases, Mkk1 and Mkk2; and a MAP kinase, Slt2/Mpk1 (Gustin et al., 1998; Mellor \& Parker, 1998; Heinisch et al., 1999). Signalling through MAP kinase cascades results in activation of MAP kinases by dual phosphorylation of the conserved threonine and tyrosine residues in subdomain VIII 
(Cobb \& Goldsmith, 1995). Activation of MAP kinases typically leads to the activation of downstream transcription factors, and consequently to changes in gene expression patterns. Known outputs of Slt2 activation are increased expression of $F K S 2$ and several other genes encoding cell-wall-related proteins (Zhao et al., 1998; Jung \& Levin, 1999), signalling to the actin cytoskeleton (Helliwell et al., 1998) and increased thermotolerance after preceding mild heat treatment (Kamada et al., 1995). Loss of any of the components of the PKC1-MAPK cascade results in osmotic-remedial cell lysis and downregulation of a subset of cell wall genes, demonstrating a regulatory role for this pathway in cell wall construction (Igual et al., 1996; Gustin et al., 1998; Mellor \& Parker, 1998).

Activation of the PKC1 pathway seems to be mediated through a family of plasma membrane-localized sensors, Wsc1-4, Mid2 and its homologue Mtl1 (Verna et al., 1997; Gray et al., 1997; Jacoby et al., 1998; Rajavel et al., 1999; Ketela et al., 1999). Cell wall damage and growth at elevated temperatures generate a signal that is transduced from Hcs77/Wsc1 via the GTPase Rho1 to Pkc1 and results in depolarization of the actin cytoskeleton independent of the MAP kinase cascade (Delley \& Hall, 1999). Several cell wall mutants show enhanced GEF activity towards Rho1 (Bickle et al., 1998) and require Mid2 (Ketela et al., 1999) or Pkc1 (Roemer et al., 1994; Garrett-Engele et al., 1995; Popolo et al., 1997) for survival, suggesting that cell wall stress in these mutants is perceived and signalled through this pathway.

Here, we analyse Slt 2 activation in several cell wall mutants and in cells with an altered cell wall due to treatment with Calcofluor white (CFW), a fluorescent dye that hinders normal cell wall assembly, and with Zymolyase, a cell-wall-degrading enzyme preparation. We found dual phosphorylation of Slt 2 and induction of FKS2-lacZ expression in an Slt2-dependent manner in response to these wall-weakening conditions. Additionally, we show that Slt2 is required for increased resistance to glucanase digestion and heat shock in response to cell wall stress.

\section{METHODS}

Strains and plasmids. Escherichia coli strain DH $5 \alpha$ was used for plasmid analysis and subcloning. Saccharomyces cerevisiae strains kre 1::HIS3 and kre9::HIS3, and their isogenic wildtype SEY6210 (MATa leu2-3,112 ura3-52 his3- 4200 lys2-801 $\operatorname{trp1}-\Delta 901$ suc2- $\Delta$ ) were kindly provided by Dr H. Bussey.

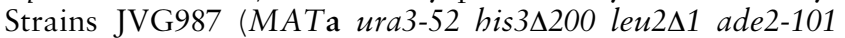
lys2-801 bar1 $:: L E U 2)$ and the isogenic hcs77::LEU2 (JVG1079) were provided by Dr J. V. Gray. Strain W303-1A (MATa ade2-1 can1-100 trp1-1 ura3-1 his3-11,15 leu2-3,112) and the isogenic sms1(mid2)::URA3 were obtained from Dr Y. Kikuchi. The other deleted genes were all replaced by HIS3

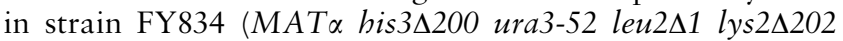
trp1 $\Delta 63)$ resulting in strains $f k s 2 \Delta$ (AR101), slt2 $\Delta$ (EV71),

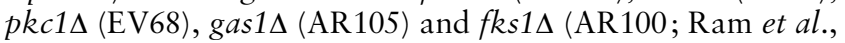
1998), and in FY1679-28c (MATa his3 300 ura3-52 leu $2 \Delta 1$ trp1 $\Delta 63)$ resulting in strain slt2 $(\mathrm{FYDK})$.

Plasmids FKS2-lacZ [FKS2(-928 to - 1)-lacZ] and FKS2 $2^{706}$
lacZ [FKS2(-706 to -1)-lacZ] contain, respectively, 928 bp and 706 bp of the FKS2 upstream non-coding region in front of the bacterial lacZ gene (Zhao et al., 1998) and were kindly provided by Dr D. Levin. Plasmid TIR1-lacZ (pLGDSRP5'; Marguet \& Lauquin, 1986) contains $2 \cdot 2 \mathrm{~kb}$ of the TIR1 upstream region and the first 58 codons of TIR 1 in-frame with the $l a c Z$ gene and was a kind gift from Dr G. Lauquin. All three reporter construct plasmids are based on the same yeast episomal plasmid containing a $2 \mu$ origin of replication and URA3 as selectable marker (Marguet \& Lauquin, 1986; Zhao et al., 1998).

Deletions. Gene deletions were essentially performed using the method described by Baudin et al. (1993). In short, disruption cassettes consisting of HIS3 flanked by 50 nucleotides identical to the targeted genes, allowing homologous recombination, were constructed in a PCR. The YDp-H plasmid (Berben et al., 1991) was used as template in the PCR for the disruption cassettes. Oligonucleotides 5'-GTCATGAGTT TTTCACAATT GGAGCAGAAC ATTAAAAAAA AGATAGCCGT GAATTCCCGG GGATCCG (EV21) and 5'-TCTTCATAAA TCCAAATCAT CTGGCATAAA GGAAAATCCT CTAAACTCTT AAGCTAGCTT GGCTGCAG (EV22) were used for the PCR of $p k c 1:: H I S 3$. Oligonucleotides 5'-GAGATGGCTG ATAAGATAGA GAGGCATACT TTCAAGGTCT TCAATCAAGA GAATTCCCGG GGATCCG (EV25) and 5'-GTCCTAAAAA TATTTTCTAT CTAATCCAAA CTCCAGCTCT TTTTCAAGGT AAGCTAGCTT GGCTGCAG (EV26) were used for the PCR of slt2::HIS3. Deletion of the targeted genes in strain FY834 was confirmed by PCR using primers $5^{\prime}$ GGGGTACCTG TATTTATGAG GCATTGCTAT CTT (EV23) and 5'-GGGGTACCGA GGTTTTTCAT ATGCATGCTC C (EV24) for $p k c 1:$ :HIS3, and 5'-GGGGTACCGT TCGAATACTT GTGAGCCTA (EV27) and 5'-GGGGTACCAG AGGCGATAAC AAACTTCCG (EV28) for slt2::HIS3.

Growth assays. The sensitivity of yeast strains to CFW or Zymolyase-100T was assayed as growth inhibition. Cells were precultured in YEPD for $24 \mathrm{~h}$ at $28{ }^{\circ} \mathrm{C}$ prior to dilution to a concentration of 75000 cells $(200 \mu \mathrm{l} \text { YEPD })^{-1}$. Growth was continued in the presence of the antifungals in flat-bottom 96well Greiner PS-microplates at $28{ }^{\circ} \mathrm{C}$ without shaking, and growth was determined as $\mathrm{OD}_{595}$ of each culture after resuspension.

$\boldsymbol{\beta}$-Galactosidase assay. Cells containing the FKS2-lacZ or TIR1-lac Z plasmids were precultured in selective medium for $24 \mathrm{~h}$ at $28^{\circ} \mathrm{C}$. Fresh precultures were used to inoculate liquid YEPD cultures without any addition or with CFW or Zymolyase-100T and the transformants were grown for an additional $4-7 \mathrm{~h}$ at $28^{\circ} \mathrm{C}$. Growth was determined as $\mathrm{OD}_{595}$ and the cells were permeabilized immediately using chloroform/SDS as described previously (Guarente, 1983). $\beta$ Galactosidase activity was determined at $30^{\circ} \mathrm{C}$ (Guarente, 1983) and was expressed in Miller units.

Detection of dually phosphorylated Slt2. Yeast cells were grown overnight to mid-exponential phase in YEPD. The cultures were then diluted in YEPD to $\mathrm{OD}_{595} 0.3$ and growth was continued for $4 \mathrm{~h}$ at $24{ }^{\circ} \mathrm{C}$ prior to collecting the cells or to treatment with CFW, Congo red or Zymolyase 100-T. Where indicated, sorbitol was added to the media to a final concentration of $1 \mathrm{M}$. Cells were collected on ice by adding $20 \mathrm{ml}$ of the culture to an equal volume of ice in a Falcon centrifuge tube and pelleted in a refrigerated centrifuge. Cells were then resuspended in $1 \mathrm{ml}$ ice-cold water and transferred to an Eppendorf tube, pelleted and immediately broken or frozen on dry ice. Cells were lysed in $120 \mu \mathrm{l}$ cold lysis buffer 
(50 mM Tris/ $\mathrm{HCl} \mathrm{pH} 7 \cdot 5,10 \%$ glycerol, $1 \%$ Triton $\mathrm{X}-100$, $0 \cdot 1 \%$ SDS, $150 \mathrm{mM} \mathrm{NaCl}, 50 \mathrm{mM} \mathrm{NaF}, 1 \mathrm{mM}$ sodium orthovanadate, $50 \mathrm{mM} \beta$-glycerol phosphate, $5 \mathrm{mM}$ Na pyrophosphate, $5 \mathrm{mM}$ EDTA, $1 \mathrm{mM}$ PMSF and the protease inhibitors tosylphenylalanine chloromethyl ketone, tosyllysine chloromethyl ketone, leupeptin, pepstatin A, antipain and aprotinin, each at $25 \mu \mathrm{g} \mathrm{ml} \mathrm{m}^{-1}$ ) by vigorous shaking with $0.45 \mathrm{~mm}$ glass beads in a fast-prep cell breaker (Bio101; level 5.5 for $25 \mathrm{~s}$ ). Cell extracts were separated from glass beads and cell debris and collected in an Eppendorf tube by centrifugation and further clarified by a $13000 \mathrm{~g}$ spin for $15 \mathrm{~min}$ at $4{ }^{\circ} \mathrm{C}$. The protein concentration of the supernatants was measured at $280 \mathrm{~nm}$ and normalized with lysis buffer. Then, $2 \times$ SDS-PAGE sample loading buffer was added and samples were boiled for $5 \mathrm{~min}$. Protein samples $(50 \mu \mathrm{g})$ were fractionated by SDS-PAGE using $8 \%$ polyacrylamide gels and transferred to nitrocellulose membranes (Hybond; Amersham). Membranes were probed with anti-phosphop44/42 MAP kinase (Thr202/Tyr204) antibody (New England Biolabs) to detect active Slt2 at 1/2000 dilution in the presence of $5 \%$ non-fat milk for $2 \mathrm{~h}$ at room temperature. The primary antibody was detected using a horseradish peroxidaseconjugated anti-rabbit antibody with the ECL detection system. To monitor the amount of Slt2, blots were stripped and reprobed with polyclonal anti-Slt2 antibodies (Martin et al., 1993) at 1/1000 dilution, followed by detection as described above.

Thermotolerance. Cells pregrown in YEPD for $24 \mathrm{~h}$ at $28{ }^{\circ} \mathrm{C}$ were diluted in YEPD to a density of $0.5 \times 10^{7}$ cells $\mathrm{ml}^{-1}$ $\left(\mathrm{OD}_{595} 0.3\right)$ and growth was continued for at least $4 \mathrm{~h}$ at $28^{\circ} \mathrm{C}$ in the presence or absence of cell-wall-destabilizing compounds. Cultures were washed and resuspended in YEPD, yielding a suspension of $\mathrm{OD}_{595} 1$. Following a heat shock of 0-20 min at $50{ }^{\circ} \mathrm{C}$, cells were plated on YEPD and incubated for $2-3 \mathrm{~d}$ at $28^{\circ} \mathrm{C}$. Colony forming units were counted and percentage survival was determined relative to cultures that were not shocked at $50^{\circ} \mathrm{C}$.

1,3- $\beta$-Glucanase sensitivity. Cells were washed and resuspended in $50 \mathrm{mM}$ Tris $/ \mathrm{HCl} \mathrm{pH} 7 \cdot 4$ to a concentration of $1.5 \times 10^{7}$ cells $\mathrm{ml}^{-1}$. $\beta$-Mercaptoethanol was added to a final concentration of $40 \mathrm{mM}$ and the cells were incubated at room temperature for $30 \mathrm{~min}$ prior to the addition of $100 \mathrm{U}$ 1,3- $\beta$-glucanase per $\mathrm{ml}$ (Quantazyme $y / g$; Quantum Biotechnologies). The decrease in $\mathrm{OD}_{595}$ was followed in time as a measure of cell lysis and was expressed as a percentage of the $\mathrm{OD}_{595}$ prior to enzyme addition.

\section{RESULTS}

\section{FKS2-lacZ expression is enhanced in cell wall mutants}

Reduced levels of $1,3-\beta$-glucan in the wall result in swollen and spherical yeast cells (Popolo et al., 1993; Ram et al., 1995; Kapteyn et al., 1997). Two mutants with less 1,3 - $\beta$-glucan in their walls, gas $1 \Delta$ and $f k s 1 \Delta$, have previously been shown to contain increased levels of Fks2, presumably as a result of a cell wall compensation mechanism induced by these mutants to maintain cell integrity (Mazur et al., 1995; Ram et al., 1998). We transformed these mutants and the wild-type strain FY834 with an FKS2-lacZ reporter construct and determined $\beta$-galactosidase activity at different growth stages. Exponentially growing FY834 cells transformed

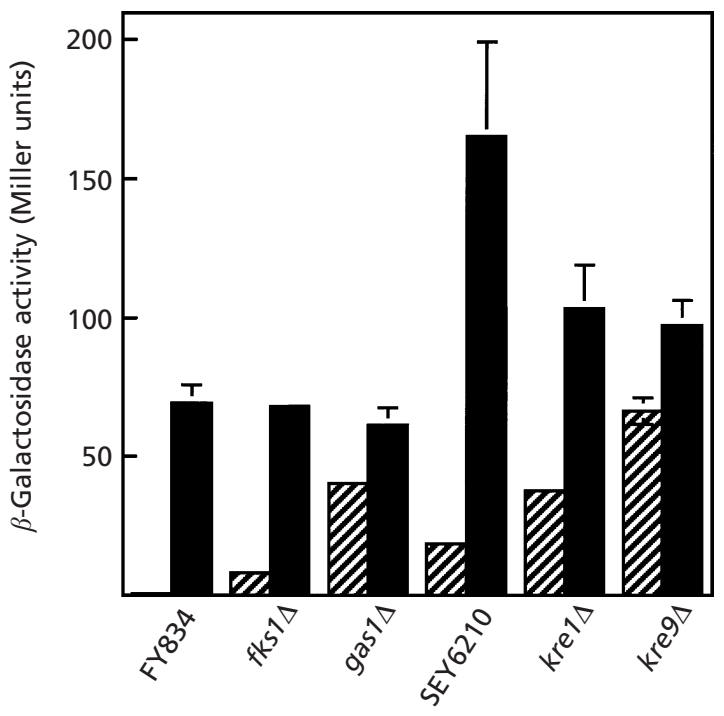

Fig. 1. Enhanced $F K S 2-l a c Z$ expression in cell wall mutants. Wild-type cells and isogenic cell wall mutants ( $f k s 1:: H I S 3$ and gas $1:: H I S 3$ in FY834 and kre1::HIS3 and kre9::HIS3 in SEY6210) were transformed with the FKS2-lacZ reporter plasmid. Transformants were precultured to saturation in selective medium prior to growth in YEPD at $28^{\circ} \mathrm{C}$. $\beta$-Galactosidase activity, expressed in Miller units, was determined at earlyexponential phase $\left(O D_{595} 1\right.$; hatched bars) or at stationary phase (black bars). $\beta$-Galactosidase activity of FY834 [FKS2-lacZ] at early-exponential phase was $0.5+0 \cdot 1$ Miller units. Values are means $\pm \operatorname{SEM}(n=6)$. Note that in several cases the standard error is too small to show in the figure.

with FKS2-lacZ showed a low basal level of $\beta$ galactosidase activity (about 0.5 Miller units) that strongly increased in stationary phase (Fig. 1). This is in accordance with the earlier reported responsiveness of this construct to stationary phase (Zhao et al., 1998). Similarly, transformants of $f k s 1 \Delta$ and gas $1 \Delta$ both showed enhanced levels of FKS2-lacZ activity in stationary phase (Fig. 1). At exponential phase, however, basal $\beta$-galactosidase activities were in both mutants significantly higher than in the wild-type (Fig. 1), reflecting a constitutive induction of the FKS2 reporter construct in these mutants, as observed previously by transcript and immunoblot analyses (Mazur et al., 1995; Ram et al., 1998).

Next, we used this reporter construct to follow FKS2 induction in mutants defective in other wall components. The extracellular proteins Kre1 and Kre9 are important for synthesis of 1,6- $\beta$-glucan. Loss of either protein alone results in reduced levels of $1,6-\beta$-glucan in the wall and concomitantly an aberrant cell wall morphology whereas simultaneous loss of both proteins is lethal (Boone et al., 1990; Brown \& Bussey, 1993). The wild-type SEY6210 [FKS2-lacZ] transformants gave a high basal level of $\beta$-galactosidase activity (about 20 Miller units) during the exponential growth phase prior to an increase in activity in stationary phase (Fig. 1). The kre1s [FKS2-lacZ] transformant showed an 


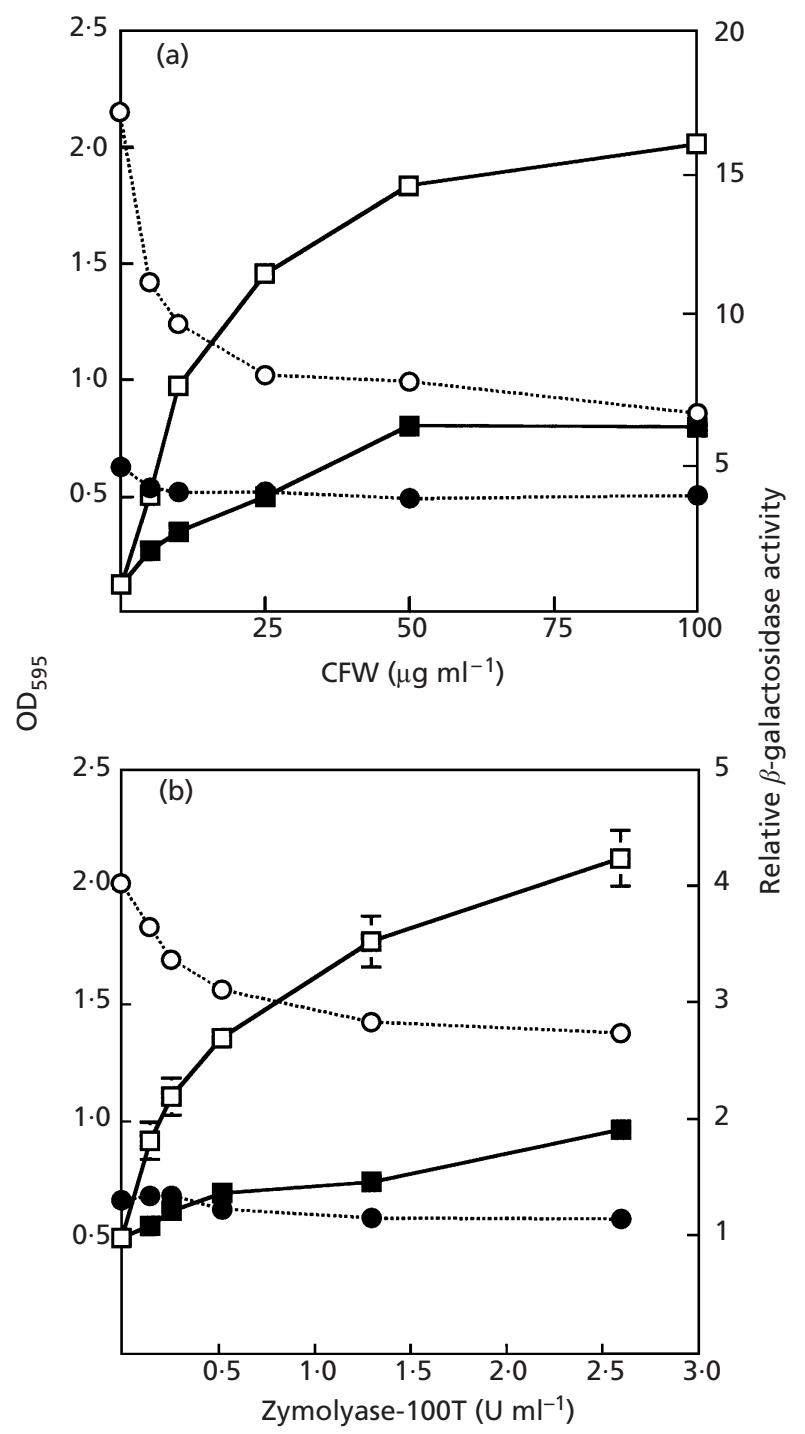

Fig. 2. Cell wall perturbation by CFW and Zymolyase-100T induces FKS2-lacZ expression. (a) FY834 [FKS2-lacZ] precultures were diluted to $\mathrm{OD}_{595} 0.25$ in YEPD without (open symbols) or with (closed symbols) $1 \mathrm{M}$ sorbitol and various amounts of CFW. Cultures were incubated at $28{ }^{\circ} \mathrm{C}$ for $6.5 \mathrm{~h}$ and $O_{595}$, as a measure of growth (dotted lines with circles), and $\beta$-galactosidase activity (solid lines with squares) were determined. $\beta$-Galactosidase activity is expressed as a ratio relative to the activity in the absence of CFW. (b) As (a) but in the presence of various amounts of Zymolyase-100T. Values are means \pm SEM $(n=4)$. Note that in several cases the standard error is too small to show in the figure.

approximate twofold increase of the basal level of activity during the exponential phase whereas in the kre9s [FKS2-lacZ] transformant the basal activity increased almost fourfold (Fig. 1).

When the gas $1 \Delta, f k s 1 \Delta, k r e 1 \Delta$ and kre9s mutants and their respective wild-types were transformed with a TIR1-lacZ reporter construct, no significant $\beta$ galactosidase activity could be detected. TIR 1 encodes a cell wall protein that is induced by growth at low temperatures and under anaerobiosis (Donzeau et al., 1996). The TIR1-lacZ reporter plasmid was functional because significant $\beta$-galactosidase activity could be obtained with FY834 and SEY6210 transformants under inductive growth conditions (data not shown). Taken together, these results show that the FKS2-lacZ construct but not the TIR1-lacZ construct can be used as reporter for cell wall compensation reactions occurring in cell wall mutants.

\section{Enhanced FKS2-lacZ expression after cell wall weakening by CFW or Zymolyase}

$\mathrm{CFW}$ is a negatively charged, fluorescent dye that is unable to pass through the plasma membrane but preferentially binds to chitin in the yeast cell wall and interferes with normal wall assembly (Pringle et al., 1989; Ram et al., 1994). We tested the effect of CFW-induced cell wall perturbation on FKS2-lacZ expression. FY834 [FKS2-lacZ] and SEY6210 [FKS2lacZ] transformants were transferred from selective medium to YEPD without or with CFW. Induction of $\beta$ galactosidase activity during a $6.5 \mathrm{~h}$ incubation period depended on the concentration of CFW but levelled off at concentrations above $50 \mu \mathrm{g} \mathrm{ml}^{-1}$ (Fig. 2a). After prolonged incubation, the cultures entered into stationary phase and FKS2-lacZ expression increased independently of the presence of CFW (data not shown).

Cell wall integrity can also be challenged by Zymolyase$100 \mathrm{~T}$, a cocktail of $1,3-\beta$-glucanase and protease activities that is commonly used to degrade yeast cell walls. FY834 cells cultured in the presence of up to $2 \cdot 6 \mathrm{U}$ of Zymolyase-100T (ml YEPD) ${ }^{-1}$ showed slightly impaired growth whereas a 10 -fold lower concentration severely slowed growth of SEY6210 cells (data not shown). Both FY834 [FKS2-lacZ] and SEY6210 [FKS2lac $Z$ ] transformants gave clear induction of $\beta$-galactosidase activity when grown in the presence of Zymolyase (Fig. $2 \mathrm{~b}$ and data not shown). Although the levels of $\beta$ galactosidase activity were much lower in FY834 [FKS2lacZ] than in SEY6210 [FKS2-lacZ] transformants, the relative increase was similar.

Addition of $1 \mathrm{M}$ sorbitol to the growth medium partially relieved growth inhibition by CFW or Zymolyase (Fig. 2 and 3 and data not shown) and was associated with reduced FKS2-lacZ expression (Fig. 2). Similar suppression of FKS2-lacZ expression was obtained when transformants were cultured in the presence of $0.8 \mathrm{M}$ $\mathrm{KCl}$ or $1 \mathrm{M}$ sucrose. The observed suppression of FKS2-lacZ expression in an osmotically supported medium suggests that loss of membrane support due to a loss in cell wall strength is a crucial step in sensing CFW- and Zymolyase-induced stress. Unlike the FKS2lacZ transformants, cells transformed with the TIR1lac $Z$ reporter construct did not give rise to detectable $\beta$ galactosidase activity when grown in the presence of identical amounts of CFW or Zymolyase (data not shown). 


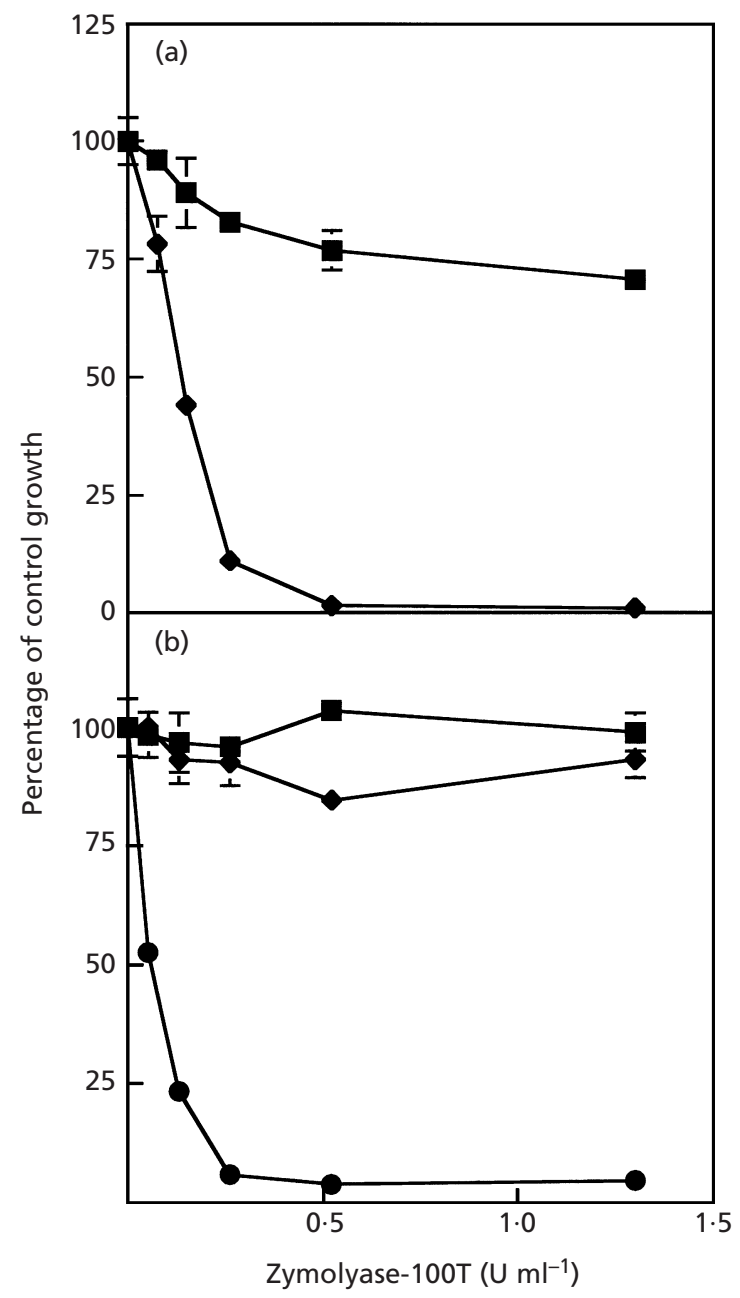

Fig. 3. $s / t 2 \Delta$ and $p k c 1 \Delta$ cells are hypersensitive to Zymolyase100T. YEPD cultures in microtitre plates without (a) or with (b) $1 \mathrm{M}$ sorbitol were inoculated with stationary-phase cells to a starting $\mathrm{OD}_{595}$ of 0.025 . Growth in the presence of the indicated amounts of Zymolyase-100T was determined as $\mathrm{OD}_{595}$ after $18 \mathrm{~h}$ growth at $28{ }^{\circ} \mathrm{C}$ and is expressed as a percentage of the $O_{595}$ in the absence of Zymolyase-100T (labelled as percentage of control growth). The $\mathrm{OD}_{595}$ after $18 \mathrm{~h}$ of growth at $28^{\circ} \mathrm{C}$ in the absence of Zymolyase-100T was (a) FY834, 7.2; slt2 $\Delta, 2 \cdot 5$; (b)

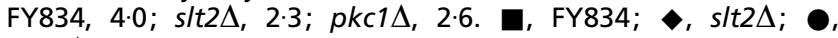
pkc1 $\Delta$. Values are means $\pm \operatorname{SEM}(n=3)$.

\section{Induction of FKS2-lacZ expression in response to cell wall perturbation fully depends on Slt2}

The combined deletion of PKC1 and several cell wall genes has been demonstrated to be lethal (Roemer et al., 1994; Garrett-Engele et al., 1995; Popolo et al., 1997). Therefore, we further investigated the requirement for PKC1 and SLT2 in the response to CFW- and Zymolyase-induced cell wall stress. Loss of SLT2 resulted in hypersensitivity to both compounds which could be completely alleviated by the addition of $1 \mathrm{M}$ sorbitol. The pkc1s mutant does not grow without osmotic support but was hypersensitive to both compounds in the presence of $1 \mathrm{M}$ sorbitol (Fig. 3 and data not shown). One explanation for these findings is that an important response triggered after cell wall perturbation is mediated through the PKC1 pathway.

The FKS2-lacZ reporter construct has been shown to respond to a variety of signals transduced by several different pathways, amongst others the PKC1 pathway, through spatially separated elements within the FKS2 promoter. The $F K S 2^{706}-l a c Z$ reporter, for example, contains a shorter fragment of the FKS2 promoter region and is therefore no longer responsive to calcineurin-transduced signals or stationary phase but remains responsive to high temperature, a known Slt2transduced signal (Zhao et al., 1998). Exponentially growing SEY 6210 cells transformed with the $F K S 2^{706}$ lac $Z$ reporter construct showed a much reduced $\beta$ galactosidase activity under non-inducing conditions compared to SEY6210 [FKS2-lacZ] transformants $(0 \cdot 5$ and 20 Miller units, respectively; Figs 1 and $4 \mathrm{a}$ ). However, a more than sixfold induction of $\beta$ galactosidase activity was observed when SEY6210 $\left[F K S 2^{706}-\right.$ lac Z cells were grown in the presence of CFW (Fig. 4a), similar to that observed in SEY6210 [FKS2lacZ] transformants under the same conditions (data not shown). These results are consistent with the proposed role for the Slt2-mediated pathway in upregulating $F K S 2-l a c Z$ expression in response to cell wall perturbation. Next, we examined FKS2-lacZ expression in an slt $2 \Delta$ strain. Stationary-phase induction of FKS2lac $Z$ occurred to the same extent in both slt $2 \Delta$ and FY834 transformants (data not shown). However, unlike FY834 [FKS2-lacZ] transformants, the isogenic slt $2 \Delta$ [FKS2-lacZ] showed no increased $\beta$-galactosidase activity when grown in the presence of sublethal concentrations of CFW or Zymolyase that allowed growth of both strains (Fig. 4b). These data demonstrate that induction of FKS2-lacZ in response to cell wall perturbation depends completely on Slt2, which is not the case for induction by stationary phase.

\section{Slt2 is activated in response to cell wall damage}

To confirm the direct involvement of Slt2 in FKS2 induction following cell wall perturbations, Slt2 phosphorylation in response to similar stimuli was examined. Recently, tyrosine phosphorylation of an overexpressed HA-epitope-tagged version of Slt 2 in response to CFW-induced cell wall stress has been shown (Ketela et al., 1999). However, MAPK activation requires phosphorylation of both conserved tyrosine and threonine residues within the activation loop (Cobb \& Goldsmith, 1995). Therefore, to follow Slt2 activation we used an anti-phospho-p44/p42 MAP kinase antibody, which recognizes the dually phosphorylated form of Slt2. Previous work using other inducing conditions has shown the specificity of this antibody in detecting the dually phosphorylated form of Slt2 by Western blotting (Verna et al., 1997; Martin et al., 2000).

Consistent with the above-described enhanced FKS2 expression in cell wall mutants, gas $1 \Delta, f k s 1 \Delta$ and kre $9 \Delta$ 

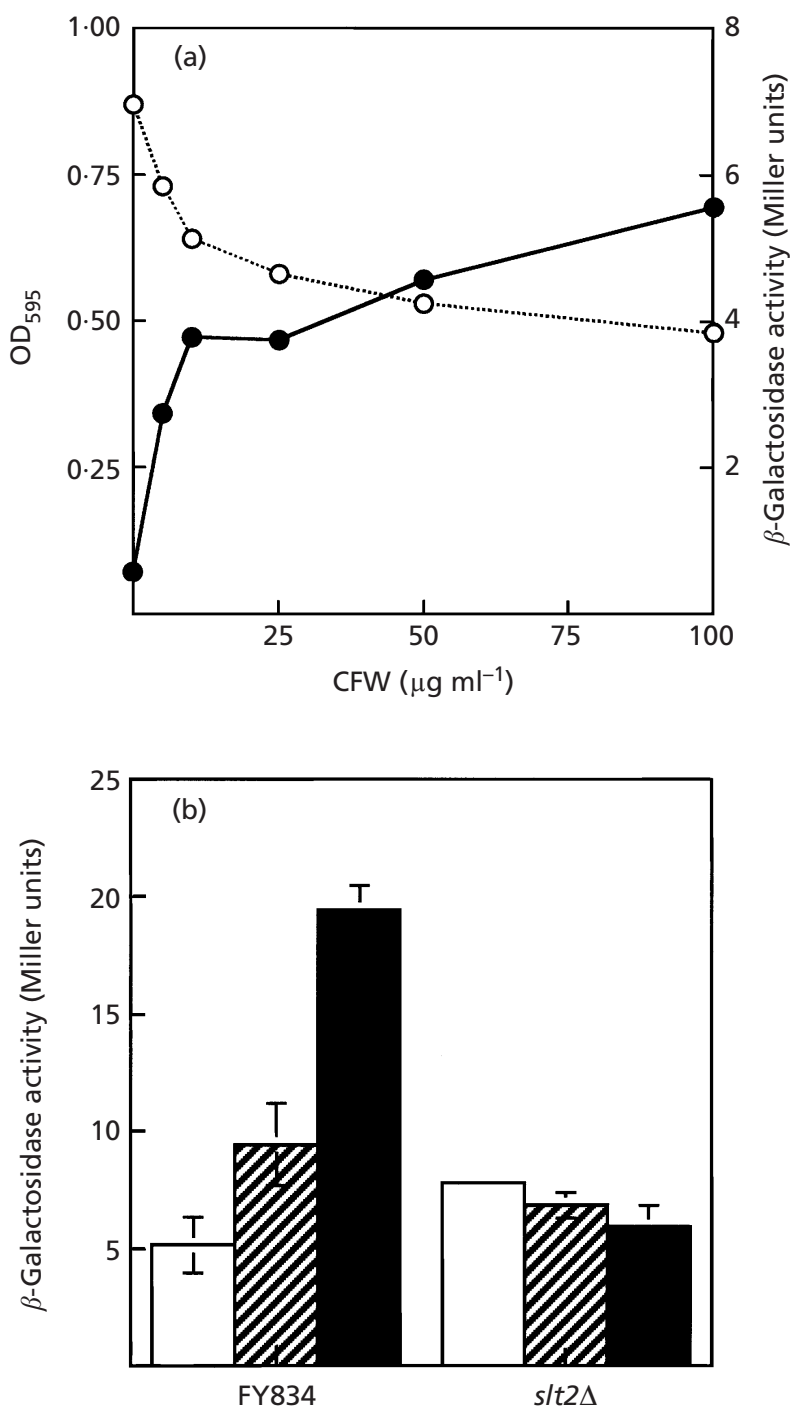

Fig. 4. $F K S 2-l a c Z$ expression in response to cell wall perturbation depends on Slt2. (a) SEY6210 cells were transformed with a shortened (FKS2 $\left.{ }^{706}-l a c Z\right)$ reporter construct that is unresponsive to stationary phase or calcineurinmediated signals (Zhao et al., 1998). Precultures of the transformants were diluted to $\mathrm{OD}_{595} 0.24$ in YEPD with the indicated amounts of CFW. Cultures were incubated at $28^{\circ} \mathrm{C}$ for $5 \mathrm{~h}$, and $\mathrm{OD}_{595}(O)$ and $\beta$-galactosidase activity, expressed as Miller units (O), were determined. (b) FY834 and s/t2A cells were transformed with the FKS2-lacZ reporter plasmid. Two independent transformants of each were precultured to saturation in selective medium prior to dilution in YEPD to yield an $\mathrm{OD}_{595}$ of $0 \cdot 3$. Cultures were incubated for $6 \mathrm{~h}$ at $28^{\circ} \mathrm{C}$ without addition (white bars), or in the presence of Zymolyase100T (0.26 U ml ${ }^{-1}$; hatched bars) or CFW $\left(10 \mu \mathrm{g} \mathrm{ml}^{-1}\right.$; black bars). The $\mathrm{OD}_{595}$ of all cultures at least doubled during the incubation period. $\beta$-Galactosidase activity was determined and is expressed in Miller units. Values are means $\pm \operatorname{SEM}(n=4)$.

mutants displayed a much higher level of dually phosphorylated Slt2 than their wild-type strains (Fig. 5a). However, whereas the strong Slt2 phosphorylation shown by gas $1 \Delta$ mutants was prevented when cells were grown in medium with $1 \mathrm{M}$ sorbitol, osmotic stabilization of the medium greatly reduced but did not totally eliminate the increase in phospho-Slt2 signal shown by fks $1 \Delta$ and kre $9 \Delta$ mutants (Fig. $5 \mathrm{a}$ ). In contrast to these mutants, lack of Kre1p did not result in a detectable increase of Slt2 phosphorylation, possibly because cell wall damage in kre1 $1 \Delta$ cells was relatively mild (Boone et al., 1990; Brown \& Bussey, 1993; see also Fig. 1).

When wild-type cells were grown in the presence of CFW $\left(10 \mu \mathrm{g} \mathrm{ml}^{-1}\right)$ a progressive increase in the level of phospho-Slt2 was detected, starting after a $10 \mathrm{~min}$ exposure (Fig. $5 \mathrm{~b}$ ). The addition of $1 \mathrm{M}$ sorbitol to the medium initially completely suppressed the activation of the pathway, but at longer incubation times the phosphorylation was not totally prevented (Fig. 5b). These data suggest that osmotic stabilization only fully suppresses the Slt2-mediated response when the cell wall is not severely stressed. In accordance with this explanation, prevention of Slt 2 activation lasted longer when cells were treated with lower CFW concentrations (data not shown). In addition, treatment of wild-type cells with either Congo red, another compound that interferes with cell wall construction (Roncero \& Duran, 1985), or with Zymolyase also resulted in a strong induction of Slt2 phosphorylation (Fig. 5c, d).

Two putative cell surface sensors, Hcs77(Wsc1/Slg1) and Mid2, have been reported to mediate the activation of the cell integrity pathway (Gray et al., 1997; Verna et al., 1997; Jacoby et al., 1998; Ketela et al., 1999; Rajavel et al., 1999). As shown in Fig. 5(e), deletion of MID2 strongly reduced dual phosphorylation of Slt2 in response to CFW-induced stress. This is consistent with recent data showing the requirement of Mid2 for CFWinduced tyrosine phosphorylation of overexpressed Slt2HA (Ketela et al., 1999). In contrast, Hcs77(Wsc1/Slg1) seems not to be required for signalling cell wall stress to the Slt2 pathway since loss of this protein did not affect CFW-induced Slt2 activation (Fig. 5e).

\section{Cell wall perturbation induces thermotolerance in an Slt2-dependent manner}

One reported output of Slt 2 activation is the acquisition of thermotolerance. Growth at slightly elevated temperatures $\left(37^{\circ} \mathrm{C}\right)$ results in a cellular response that depends in part on Slt 2 activation and allows the cells to survive an otherwise lethal heat shock at $50{ }^{\circ} \mathrm{C}$ (Kamada et al., 1995). We determined whether Slt2 activation in response to cell wall perturbation also resulted in the acquisition of thermotolerance. Loss of FKS1 resulted in a 7 -fold, and loss of GAS1 in a 200-fold higher survival after a 15 min heat shock at $50{ }^{\circ} \mathrm{C}$ compared to the wildtype strain FY834 (Fig. 6a). Similarly, enhanced thermotolerance was observed for the kre1 $\Delta$ (2-fold) and kre9s (200-fold) mutants compared to their wild-type SEY 6210 (data not shown). Growth of FY834 and SEY6210 in the presence of the cell wall perturbants CFW or Zymolyase also resulted in cells that were significantly more resistant to heat than mock-treated cells (Fig. $6 \mathrm{~b}$ and 


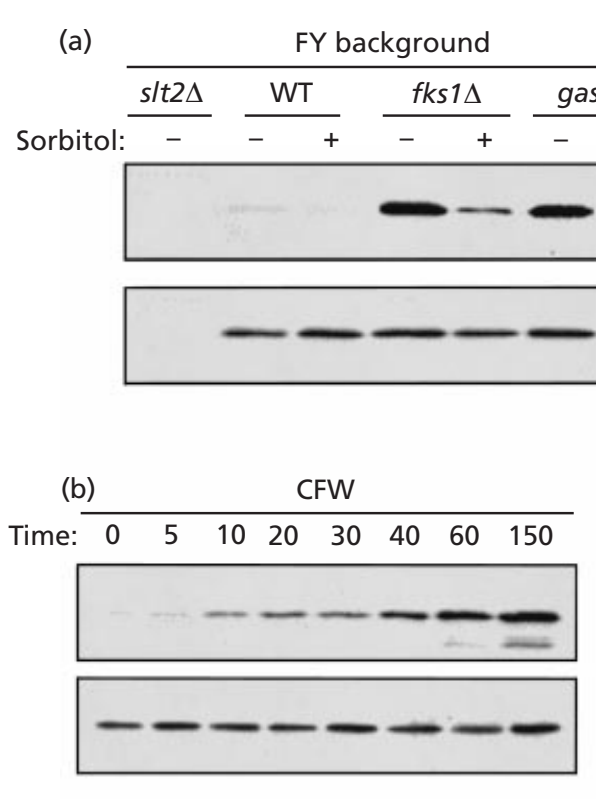

(c)

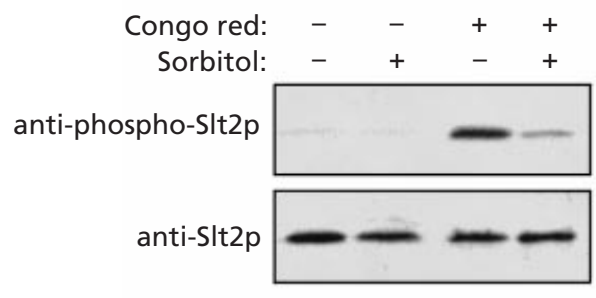

(e)

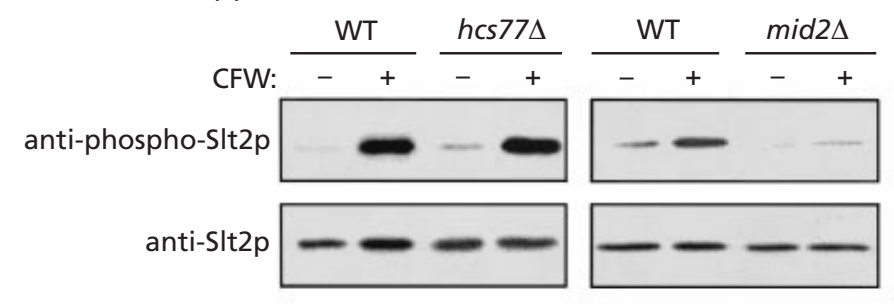

(d)
anti-phospho-SIt2p

anti-SIt2p

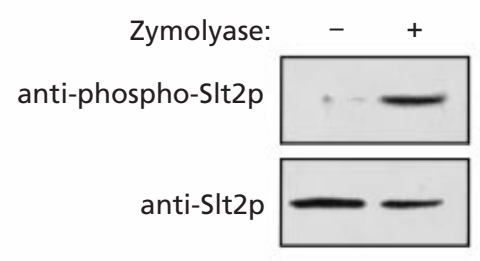

anti-phospho-SIt2p anti-SIt2p

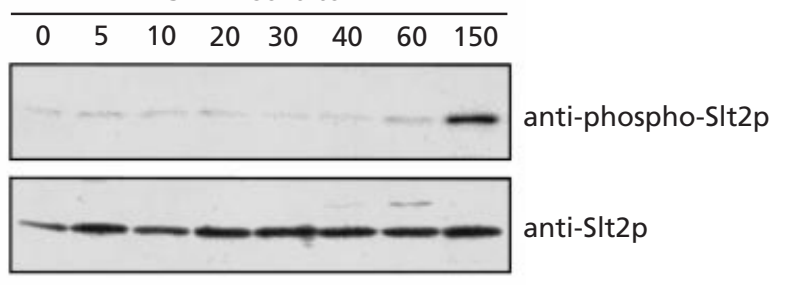



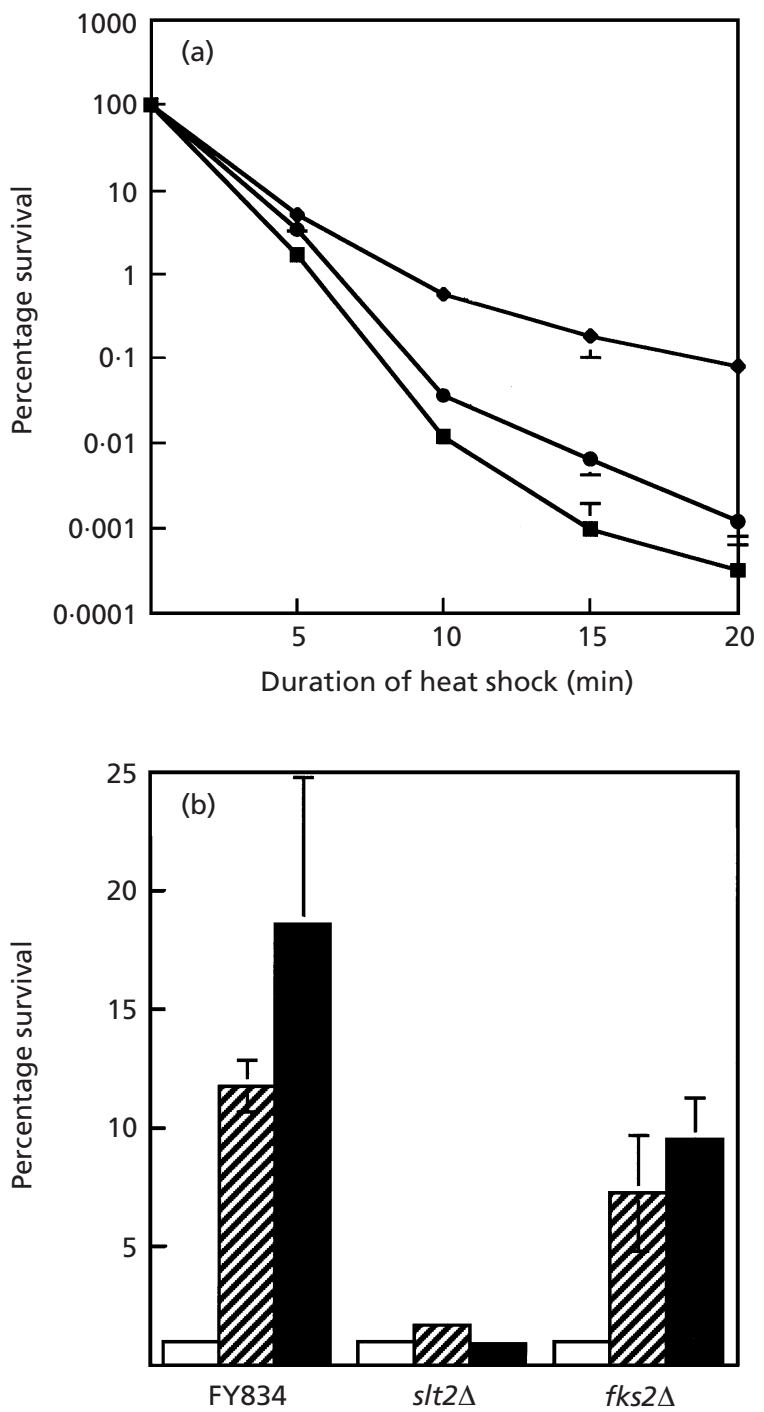

Fig. 6. Cell wall perturbation induces thermotolerance in an Slt2-dependent manner. (a) FY834 (ם), gas1 $\Delta$ ( $\bullet$ ) or $f k s 1 \Delta(\bullet)$ cells were grown in YEPD to an $\mathrm{OD}_{595}$ of 1.5 prior to heat shock at $50{ }^{\circ} \mathrm{C}$. Cells were harvested and prepared for heat treatment as described in Methods. Survival was determined as colony formation after different heat-shock periods and is expressed as percentage survival of cells that were not heat-shocked. (b) YEPD cultures were inoculated with FY834, slt2 $\Delta$ or $f k s 2 \Delta$ cells to yield a starting $O_{595}$ of 0.45 . Cultures were further incubated at $28{ }^{\circ} \mathrm{C}$ for $4.5 \mathrm{~h}$ without addition (white bars), or after addition of Zymolyase-100T $\left(0.52 \mathrm{U} \mathrm{ml}^{-1}\right.$; hatched bars) or CFW $\left(10 \mu \mathrm{g} \mathrm{ml}^{-1}\right.$; black bars). The $\mathrm{OD}_{595}$ of all cultures at least tripled during the incubation period. Cells were then heatshocked for $10 \mathrm{~min}$ at $50^{\circ} \mathrm{C}$; the percentage of surviving cells was determined and is expressed as a ratio relative to the percentage survival of heat-shocked cells that had been incubated without cell-wall-perturbing agents. Values are means $\pm \operatorname{SEM}(n=6)$.

data not shown). This response to cell wall perturbants depended on Slt2 because an slt2 $\Delta$ mutant in the FY 834 background did not acquire thermotolerance (Fig. 6b). Although upregulation of Fks2 is one of the outputs of Slt2 activation, it is not essential for the concomitant

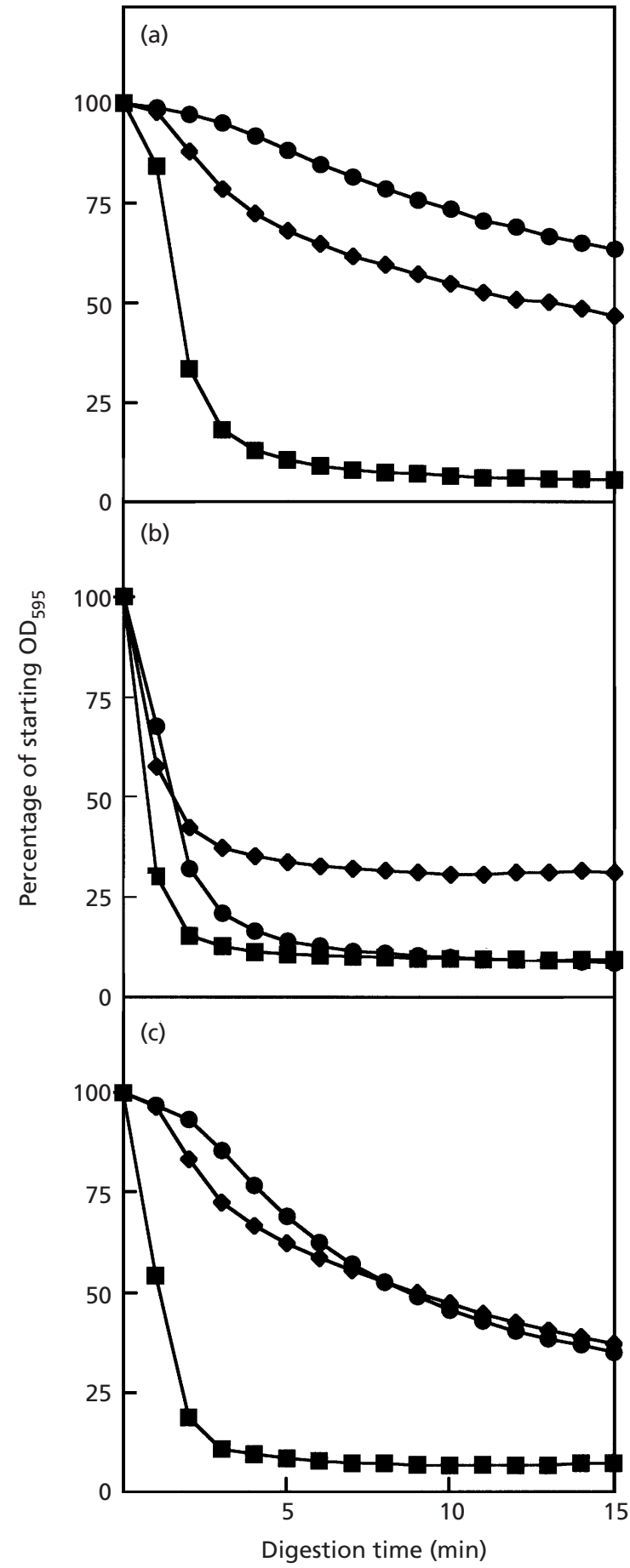

Fig. 7. Cells cultured in the presence of CFW or Zymolyase-100T display SIt2p-dependent resistance to $1,3-\beta$-glucanase digestion. YEPD cultures were inoculated with FY834 (a), s/t2A (b) or $f k s 2 \Delta$ (c) cells to yield a starting $O_{595}$ of $0 \cdot 25$. Cultures were incubated at $28^{\circ} \mathrm{C}$ for $4 \mathrm{~h}$ (FY834 and fks $2 \Delta$ ) or $6 \mathrm{~h}$ (s/t2 $2 \Delta$ ) without addition $(\mathbb{E})$, or in the presence of CFW $\left(10 \mu \mathrm{g} \mathrm{ml}^{-1}\right.$; ४) or Zymolyase-100T $\left(0.26 \mathrm{U} \mathrm{ml}^{-1} ; 0\right)$. The $\mathrm{OD}_{595}$ of all cultures at least doubled during the incubation period. Cells were washed and digested with a recombinant 1,3- $\beta$-glucanase (Quantazyme $y / g$ ) as described in Methods. The decrease in $\mathrm{OD}_{595}$ represents cell lysis and is expressed as a percentage of the starting $\mathrm{OD}_{595}$. Values are means $\pm \operatorname{SEM}(n=6)$. 
induction of heat resistance because cells lacking Fks2 still became thermotolerant in response to cell wall perturbation (Fig. 6b).

\section{Increased resistance to cell wall degradation in response to cell wall perturbation depends on Slt2}

In addition to FKS2 induction, an increase in chitin content also seems to be part of a general compensatory response to cell wall defects (Popolo et al., 1997; Ram et al., 1998). Such changes in the composition and the architecture of the cell wall (Kapteyn et al., 1999a) should affect its properties. Therefore, we examined cells with a perturbed wall for their resistance to a glucan-degrading enzyme and analysed the dependence of this on Slt2. Exponentially growing FY834, slt2 $\Delta$ and $f k s 2 \Delta$ cells were sensitive to Quantazyme, a recombinant 1,3 - $\beta$-glucanase (Fig. 7 ), but became resistant after entry into the stationary phase (data not shown) reflecting cell wall alterations upon diauxic shift (De Nobel et al., 1990). Exponentially growing gas $1 \Delta, f k s 1 \Delta$ and kre $9 \Delta$ but not kre1s cells also became more resistant to digestion by $1,3-\beta$-glucanase (data not shown). Likewise, both wild-type strains became significantly more resistant to Quantazyme digestion during exponential growth in the presence of CFW or Zymolyase (Fig. 7 and data not shown). This increased Quantazyme resistance

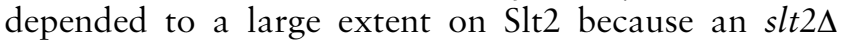
mutant remained much more sensitive when grown under the same conditions (Fig. 7). Fks2, which is upregulated after Slt 2 activation, was not required for the increased Quantazyme resistance (Fig. 7). In summary, cell wall perturbation by CFW or Zymolyase provokes an Slt2-mediated response that confers increased resistance to further cell wall degradation, probably as a result of cell wall modifications. Similar cell wall alterations seem to occur when cells enter stationary phase but these are mediated by an Slt2independent mechanism.

\section{DISCUSSION}

Many S. cerevisiae mutants defective in the synthesis of particular cell wall components, such as $1,3-\beta$-glucan, $1,6-\beta$-glucan or mannoproteins, show a characteristic set of alterations in the composition and architecture of their walls. Chitin deposition is strongly increased (Dallies et al., 1998; Kapteyn et al., 1999a) and becomes directly linked to 1,6- $\beta$-glucan (Kapteyn et al., 1997). In addition, the expression levels of several cell wall proteins and of the alternative subunit of $1,3-\beta$-glucan synthase, Fks2, are upregulated. It has been proposed that these changes are part of a compensation mechanism in response to cell wall weakening (Popolo et al., 1997; Ram et al., 1998; Kapteyn et al., 1999a; Smits et al., 1999). Such a mechanism might also protect fungal cells against cell-wall-degrading enzymes, which are frequently present in their natural environment. For example, mycoparasites and plants infected with fungi secrete large amounts of glucanases and chitinases (Lamb et al., 1989; Lorito et al., 1998).
The PKC1 pathway is believed to regulate cell integrity because loss of components in this pathway results in cell lysis that can be prevented by providing osmotic support (Gustin et al., 1998; Mellor \& Parker, 1998). This notion is further supported by the observation that the expression of several genes involved in cell wall assembly seems to be controlled by this pathway (Igual et al., 1996; Jung \& Levin, 1999). Specifically, the temperature-induced expression of Fks 2 has been shown to be one of the outputs of Slt2 activation (Zhao et al., 1998). Activation of the cell integrity pathway has been reported in response to heat and hypotonic stress and during polarized growth (Levin et al., 1994; Gustin et al., 1998; Mellor \& Parker, 1998). These conditions might activate the PKC1 pathway by challenging cell wall integrity indirectly. Furthermore, enhanced GDP/ GTP exchange activity towards Rho1, an activator of Pkc1 (Nonaka et al., 1995; Kamada et al., 1996) has been found in cell wall mutants (Bickle et al., 1998). In agreement with this, Hcs77, Rho1 and Pkc1 are required for depolarization of the actin cytoskeleton in response to heat stress and cell wall degradation (Delley \& Hall, 1999). These observations suggest that a decrease in cell wall integrity activates Pkc1. Since activation of Slt2 depends on Pkc1 and loss of Slt2 results in fragile cells (Torres et al., 1991; Lee et al., 1993; Martin et al., 1993), a role for Slt 2 in transducing the signal elicited by cell wall stress could also be envisioned. However, at present it is unclear whether all the reported outputs generated by cell wall perturbation depend on Slt 2 . In fact, although stress-induced actin depolarization depends on Pkc1, it does not require the downstream MAP kinase cascade (Delley \& Hall, 1999). In addition, activation of Slt2 as a consequence of cell wall weakening has not been demonstrated unequivocally. For example, Ketela et al. (1999) recently found increased tyrosine phosphorylation of an overexpressed HA-tagged form of Slt2 in cells grown in the presence of CFW. However, no readily apparent changes in the amount of phosphotyrosine of native Slt2 were detected under those conditions. Furthermore, MAP kinase activation requires dual phosphorylation of threonine and tyrosine residues and the occurrence in yeast of tyrosinephosphorylated but nevertheless inactive Slt 2 has been reported (Buehrer \& Errede, 1997).

Here, we used two readouts for Slt2-mediated signalling: antibodies that detect the dually (threonine and tyrosine) phosphorylated form of Slt2 and FKS2-lacZ reporter constructs. Increased dual phosphorylation of Slt2 and Slt2-dependent FKS2-lacZ expression were found in gas $1, f k s 1$ and $k r e 9$ which are cell wall mutants, and in cells treated with cell-wall-destabilizing agents. This response was partially or totally prevented when $1 \mathrm{M}$ sorbitol was added to the medium.

Taken together, these results clearly show the following. (i) Slt 2 is activated in response to defects in the cell wall; this activation is likely to mediate the compensation reactions occurring in damaged cells to ensure their integrity. (ii) Osmotic stabilization of the plasma membrane in the presence of a defective cell wall can 
prevent stimulation of the pathway. This effect depends on the extent of the cell wall damage and indicates that at least a mild cell wall stress is not sensed under such conditions. These conclusions are consistent with gas1 and $f k s 1$ mutants requiring a functional Pkc1 pathway for survival (Garrett-Engele et al., 1995; Popolo et al., 1997; Turchini et al., 2000) and with the hypersensitivity of slt 2 mutants to cell wall perturbing agents (Fig. 3).

Previously, Ketela et al. (1999) reported that tyrosine phosphorylation of overexpressed Slt2-HA in response to CFW-induced cell wall perturbation depends on the putative cell surface sensor Mid2. Our results confirm the role of Mid2 in sensing cell wall stress since we found no activation of Slt 2 in mid $2 \Delta$ cells stressed with CFW. In contrast, the putative cell integrity sensor, Hcs77, seems not to have a role in sensing cell wall defects and activating the MAP kinase cascade (Fig. 5e). Interestingly, Hcs77 but not Mid2 is required for Slt2independent actin depolarization in response to heat or cell wall damage (Delley \& Hall, 1999). These results suggest that cell wall damage can be sensed by at least two different cell surface proteins each triggering a different response. The Hcs77 homologues, Wsc2 and Wsc3 (Verna et al., 1997), might also be involved in sensing cell wall damage.

The Slt2-mediated increases in thermotolerance and glucanase resistance displayed by cells with an altered cell wall reflect how cells rely on a Slt2-mediated compensation mechanism to face wall-related stress. This also indicates the significance of the modifications in the cell wall architecture of cells in which this mechanism has been triggered. The exact changes in the wall responsible for altered sensitivity to $1,3-\beta$-glucanase digestion are at present unknown. Induction of Fks2 is not essential because an $f k s 2 \Delta$ strain gave a similar response after cell wall perturbation. Possibly, the strongly increased deposition of chitin in the lateral walls that has been reported for many cell wall mutants, including gas $1 \Delta$ and $f k s 1 \Delta$ cells (Dallies et al., 1998; Kapteyn et al., 1997, 1999b) and for cells stressed with CFW (Roncero \& Duran, 1985; Ketela et al., 1999) is responsible for the increased glucanase resistance. In addition, growth in the presence of CFW reduces the permeability of the yeast wall (De Nobel et al., 1990), suggesting enhanced incorporation of cell wall mannoproteins that could also account for this resistance. Further study is also required to determine whether increased thermotolerance in these cells depends on concurrent cell wall alterations. Unlike induction by cell wall perturbation, enhanced resistance to degradation by $1,3-\beta$-glucanase at stationary phase is independent of Slt2. This indicates that alternative signal transduction pathways might be responsible for cell wall alterations induced at this stage.

\section{ACKNOWLEDGEMENTS}

We are indebted to Drs H. Bussey, G. Lauquin, Y. Kikuchi, J. V. Gray and D. Levin for providing us with valuable strains and plasmids, to Edwin Vink and Marta Flández for strain constructions and to Dr P. de Groot for critically reading the manuscript. This work was financially supported by a grant from the Dutch Ministry of Economic Affairs and from CICYT (Ministerio de Educación y Cultura, Spain; BIO980726). Cristina Ruiz was the recipient of a Pre-doctoral Fellowship from Comunidad Autónoma de Madrid.

\section{REFERENCES}

Baudin, A., Ozier-Kalogeropoulos, O., Denouel, A., Lacroute, F. \& Cullin, C. (1993). A simple and efficient method for direct gene deletion in Saccharomyces cerevisiae. Nucleic Acids Res 21, 3329-3330.

Berben, G., Dumont, J., Gilliquet, V., Bolle, P. A. \& Hilger, F. (1991). The YDp plasmids: a uniform set of vectors bearing versatile gene disruption cassettes for Saccharomyces cerevisiae. Yeast 7, 475-477.

Bickle, M., Delley, P.-A., Schmidt, A. \& Hall, M. N. (1998). Cell wall integrity modulates $\mathrm{RHO} 1$ activity via the exchange factor ROM2. EMBO J 17, 2235-2245.

Boone, C., Sommer, S. S., Hansel, A. \& Bussey, H. (1990). Yeast $K R E$ genes provide evidence for a pathway of cell wall betaglucan assembly. J Cell Biol 110, 1833-1843.

Brown, J. L. \& Bussey, H. (1993). The yeast KRE9 gene encodes an O glycoprotein involved in cell surface beta-glucan assembly. Mol Cell Biol 13, 6346-6356.

Buehrer, B. M. \& Errede, B. (1997). Coordination of the mating and cell integrity mitogen-activated protein kinase pathways in Saccharomyces cerevisiae. Mol Cell Biol 17, 6517-6525.

Cobb, M. H. \& Goldsmith, E. J. (1995). How MAP kinases are regulated. J Biol Chem 270, 14843-14846.

Dallies, N., Francois, J. \& Pacquet, V. (1998). A new method for quantitative determination of polysaccharides in the yeast cell wall. Application to the cell wall defective mutants of Saccharomyces cerevisiae. Yeast 14, 1297-1306.

Delley, P.-A. \& Hall, M. (1999). Cell wall stress depolarizes cell growth via hyperactivation of RHO1. J Cell Biol 147, 1-12.

De Nobel, H., Klis, F. M., Priem, J., Munnik, T. \& Van den Ende, H. (1990). The glucanase-soluble mannoproteins limit cell wall porosity in Saccharomyces cerevisiae. Yeast 6, 491-499.

Donzeau, M., Bourdineaud, J.-P. \& Lauquin, G. J.-M. (1996). Regulation by low temperatures and anaerobiosis of a yeast gene specifying a putative GPI-anchored plasma membrane. Mol Microbiol 20, 449-459.

Garrett-Engele, P., Moilanen, B. \& Cyert, M. (1995). Calcineurin, the yeast $\mathrm{Ca}^{2+} /$ Calmodulin-dependent protein phosphatase, is essential in yeast mutants with cell integrity defects and in mutants that lack a functional vacuolar $\mathrm{H}^{+}$-ATPase. Mol Cell Biol 15, 4103-4114.

Gray, J. V., Ogas, J. P., Kamada, Y., Stone, M., Levin, D. E. \& Herskowitz, I. (1997). A role for the Pkc1 MAP kinase pathway of Saccharomyces cerevisiae in bud emergence and identification of a putative upstream regulator. EMBO J 16, 4924-4937.

Guarente, L. (1983). Yeast promoters and lacZ fusions designed to study expression of cloned genes in yeast. Methods Enzymol 101, 181-191.

Gustin, M. C., Albertyn, J., Alexander, M. \& Davenport, K. (1998). MAP kinase pathways in the yeast Saccharomyces cerevisiae. Microbiol Mol Biol Rev 62, 1264-1300.

Heinisch, J. J., Lorberg, A., Schmitz, H.-P. \& Jacoby, J. J. (1999). The protein kinase C-mediated MAP kinase pathway involved in 
the maintenance of cellular integrity in Saccharomyces cerevisae. Mol Microbiol 32, 671-680.

Helliwell, S. B., Schmidt, A., Ohya, Y. \& Hall, M. N. (1998). The Rho1 effector Pkc1, but not Bni1, mediates signalling from Tor2 to the actin cytoskeleton. Curr Biol 8, 1211-1214.

Igual, J. C., Johnson, A. L. \& Johnston, L. H. (1996). Coordinated regulation of gene expression by the cell cycle transcription factor SWI4 and the protein kinase C MAP kinase pathway for yeast cell integrity. $E M B O J \mathbf{1 5}, 5001-5013$.

Jacoby, J. J., Nilius, S. M. \& Heinisch, J. J. (1998). A screen for upstream components of the yeast protein kinase $\mathrm{C}$ signal transduction pathway identifies the product of the SLG1 gene. Mol Gen Genet 258, 148-155.

Jung, U. S. \& Levin, D. E. (1999). Genome-wide analysis of gene expression regulated by the yeast cell wall integrity signalling pathway. Mol Micobiol 34, 1049-1057.

Kamada, Y., Jung, U. S., Piotrowski, J. \& Levin, D. E. (1995). The protein kinase C-activated MAP kinase pathway of Saccharomyces cerevisiae mediates a novel aspect of the heat shock response. Genes Dev 9, 1559-1571.

Kamada, Y., Qadota, H., Python, C. P., Anraku, Y., Ohya, Y. \& Levin, D. E. (1996). Activation of yeast protein kinase $C$ by Rho1 GTPase. J Biol Chem 271, 9193-9196.

Kapteyn, J. C., Ram, A. F. J., Groos, E. M., Kollar, R., Montijn, R. C., Van den Ende, H., Llobel, A., Cabib, E. \& Klis, F. M. (1997). Altered extent of cross-linking of $\beta 1,6$-glucosylated mannoproteins to chitin in Saccharomyces cerevisiae mutants with reduced cell wall $\beta 1,3$-glucan content. J Bacteriol 179, 6279-6284.

Kapteyn, J. C., Van den Ende, H. \& Klis, F. M. (1999a). The contribution of cell wall proteins to the organization of the yeast cell wall. Biochim Biophys Acta 1426, 373-383.

Kapteyn, J. C., Van Egmond, P., Sievi, E., Van den Ende, H., Makarow, M. \& Klis, F. M. (1999b). The contribution of the $\mathrm{O}$ glycosylated protein Pir2p/Hsp150 to the construction of the yeast cell wall in wild-type cells and $\beta 1,6$-glucan-deficient mutants. Mol Microbiol 31, 1835-1844.

Ketela, T., Green, R. \& Bussey, H. (1999). Saccharomyces cerevisiae Mid2p is a potential cell wall stress sensor and upstream activator of the PKC1-MPK1 cell integrity pathway. J Bacteriol 181, $3330-3340$.

Lamb, C. J., Lawton, M. A., Dron, M. \& Dixon, R. A. (1989). Signals and transduction mechanisms for activation of plant defenses against microbial attack. Cell 56, 215-224.

Lee, K. S., Irie, K., Gotoh, Y., Watanabe, Y., Araki, H., Nishida, E., Matsumoto, K. \& Levin, D. E. (1993). A yeast mitogen-activated protein kinase homolog (Mpk1p) mediates signalling by protein kinase C. Mol Cell Biol 13, 3067-3075.

Levin, D. E., Bowers, B., Chen, C. Y., Kamada, Y. \& Watanabe, M. (1994). Dissecting the protein kinase C/MAP kinase signalling pathway of Saccharomyces cerevisiae. Cell Mol Biol Res 40, 229-239.

Lorito, M., Woo, S. L., Garcia Fernandez, I. \& 10 other authors (1998). Genes from mycoparasitic fungi as a source for improving plant resistance to fungal pathogens. Proc Natl Acad Sci USA 95, 7860-7865.

Marguet, D. \& Lauquin, G. J.-M. (1986). The yeast SRP gene: positive modulation by glucose of its transcriptional expression. Biochem Biophys Res Commun 138, 297-303.

Martin, H., Arroyo, J., Sanchez, M., Molina, M. \& Nombela, C. (1993). Activity of the yeast MAP kinase homologue Slt2 is critically required for cell integrity at $37^{\circ} \mathrm{C}$. Mol Gen Genet 241, $177-184$
Martin, H., Rodriguez-Pachon, J. M., Ruiz, C., Nombela, C. \& Molina, M. (2000). Regulatory mechanisms for modulation of signaling through the cell integrity Slt2-mediated pathway in Saccharomyces cerevisiae. J Biol Chem 275, 1511-1519.

Mazur, P., Morin, N., Baginsky, W., El-Sherbeini, M., Clemas, J. A., Nielsen, J. B. \& Foor, F. (1995). Differential expression and function of two homologous subunits of yeast $1,3-\beta$-D-glucan synthase. Mol Cell Biol 15, 5671-5681.

Mellor, H. \& Parker, P. J. (1998). The extended protein kinase C superfamily. Biochem J 332, 281-292.

Nonaka, H., Tanaka, K., Hirano, H., Fujiwara, T., Kohno, H., Umikawa, M., Mino, A. \& Takai, Y. (1995). A downstream target of RHO1 small GTP-binding protein is PKC1, a homolog of protein kinase $\mathrm{C}$, which leads to activation of the MAP kinase cascade in Saccharomyces cerevisiae. EMBO J 14, 5931-5938.

Popolo, L. \& Vai, M. (1999). The Gas1 glycoprotein, a putative wall polymer cross-linker. Biochim Biophys Acta 1426, 385-400.

Popolo, L., Vai, M., Gatti, E., Porello, S., Bonafante, P., Balestrini, R. \& Alberghina, L. (1993). Physiological analysis of mutants indicates involvement of the Saccharomyces cerevisiae glycosylphosphatidylinositol-anchored protein gp115 in morphogenesis and cell separation. J Bacteriol 175, 1879-1885.

Popolo, L., Gilardelli, D., Bonafante, P. \& Vai, M. (1997). Increase in chitin as an essential response to defects in assembly of cell wall polymers in the ggp1 $1 \Delta$ mutant of Saccharomyces cerevisiae. J Bacteriol 179, 463-469.

Pringle, J. R., Preston, R. A., Adams, A. E. M., Stearns, T., Drubin, D. G., Haarer, B. K. \& Jones, E. W. (1989). Fluorescence microscopy methods for yeast. Methods Cell Biol 31, 357-435.

Rajavel, M., Philip, B., Buehrer, B. M., Errede, B. \& Levin, D. E. (1999). Mid2 is a putative sensor for cell integrity signaling in Saccharomyces cerevisiae. Mol Cell Biol 19, 3969-3976.

Ram, A. F. J., Wolters, A., Ten Hoopen, R. \& Klis, F. M. (1994). A new approach for isolating cell wall mutants in Saccharomyces cerevisiae by hypersensitivity to Calcofluor white. Yeast 10, 1019-1030.

Ram, A. F. J., Brekelmans, S. S. C., Oehlen, L. J. W. M. \& Klis, F. M. (1995). Identification of two cell cycle regulated genes affecting the $\beta$-1,3-glucan content of cell wall in Saccharomyces cerevisiae. FEBS Lett 358, 165-170.

Ram, A. F. J., Kapteyn, J. C., Montijn, R. C., Caro, L. H. P., Douwes, J. E., Baginsky, W., Mazur, P., Van den Ende, H. \& Klis, F. M. (1998). Loss of the plasma membrane-bound protein Gas1p in Saccharomyces cerevisiae results in the release of $\beta$-1,3-glucan into the medium and induces a compensation mechanism to ensure cell wall integrity. J Bacteriol 180, 1418-1424.

Roemer, T., Paravicini, G., Payton, M. A. \& Bussey, H. (1994). Characterization of the yeast (1-6)-beta-glucan biosynthetic components, Kre6p and Skn1p, and genetic interactions between the PKC1 pathway and extracellular matrix assembly. J Cell Biol 127, 567-579.

Roncero, C. \& Duran, A. (1985). Effect of Calcofluor white and Congo red on fungal cell wall morphogenesis: in vivo activation of chitin polymerization. J Bacteriol 163, 1180-1185.

Smits, G. J., Kapteyn, J. C., Van den Ende, H. \& Klis, F. M. (1999). Cell wall dynamics in yeast. Curr Opin Microbiol 2, 348-352.

Torres, L., Martin, H., Garcia-Saez, M. I., Arroyo, J., Molina, M., Sanchez, M. \& Nombela, C. (1991). A protein kinase gene complements the lytic phenotype of Saccharomyces cerevisiae lyt 2 mutants. Mol Microbiol 5, 2845-2854.

Turchini, A., Ferrario, L. \& Popolo, L. (2000). Increase of external 
osmolarity reduces morphogenetic defects and accumulation of chitin in a gas 1 mutant of Saccharomyces cerevisiae. J Bacteriol 182, 1167-1171.

Verna, J., Lodder, A., Lee, K., Vagts, A. \& Ballester, R. (1997). A family of genes required for maintenance of cell wall integrity and for the stress response in Saccharomyces cerevisiae. Proc Natl Acad Sci USA 94, 13804-13809.
Zhao, C., Jung, U. S., Garrett-Engele, P., Roe, T., Cyert, M. S. \& Levin, D. E. (1998). Temperature-induced expression of yeast FKS2 is under the dual control of protein kinase $\mathrm{C}$ and calcineurin. Mol Cell Biol 18, 1013-1022.

Received 15 March 2000; revised 5 June 2000; accepted 9 June 2000. 